\title{
Offensive jokes: How do they impact long-term relationships?
}

JEFFREY A. HALL and KEN SERENO

Abstract

This article explores the impact of the use of negative humor on relational satisfaction and the importance of humor in long-term relationships from a coorientation perspective. Dyadic data from 123 couples were gathered using a survey measuring positive and negative humor use. These data were analyzed using structural equations modeling and the Actor-Partner Independence Model (Kenny et al. 2006: 144). Negative humor weakly predicted relational outcomes, but was valuable when partners saw themselves as possessing a shared sense of humor. Men acknowledge that their own public negative humor use negatively impacts the importance of humor in their relationship. Perceived similarity in negative humor use positively predicts relational satisfaction for both partners, and positively predicts the importance of humor for men, regardless of how much positive humor the couple uses. Accurately knowing a partner's negative humor use, or having greater understanding, negatively predicted relational outcomes.

Keywords: Humor; offensive jokes; coorientation; relational satisfaction.

Humor has been identified as one of the top ten forms of communication sustaining intimate relationships among couples (Alberts et al. 2005: 310). The value of humor lies in what it communicates about the relationship between the joker and the audience. Although a joke might not be objectively humorous, it can be an important and positive component of a couple's relationship (Bippus 2000: 398). One of the most important effects of humor is its ability to preserve and maintain relational satisfaction, but it is unclear what types of humor bring about these positive effects. The effects of exposure to sexist (Ford et al. 2001: 
677) and cruel jokes (Herzog and Anderson 2000: 333) have been explored in terms of humor appreciation, but the effects of negative humor on long-term relationships are less well understood. The present study explores the relationship between the use of negative or offensive humor and relational outcomes from a coorientation perspective, which explores both partners' perception of their own humor use and that of their partner.

\section{Humor and marital satisfaction}

Humor is inherently shared. Humor requires an audience, and in a marriage or long-term relationship the audience is often one's partner (Alberts et al. 2005: 310). Research indicates that relational humor is used to bridge differences (Seckman and Couch 1989: 331), create relational solidarity (Bippus 2000: 413; Hay 2000: 717), and enhance closeness (Lauer et al. 1990: 193; Ziv 1988: 225). The benefits of humor use in the context of a long-term relationship have been well documented. Ziv and colleagues (1988: 223; Ziv and Gadish 1989: 759) conducted some of the first studies on the use of humor in long-term relationships. They found that more than $92 \%$ of the couples surveyed believed that humor contributed to married life positively. In a follow-up study, Ziv and Gadish (1989: 764) found that the highest correlation was between wives' marital satisfaction and their perception of their husbands' humor use. The second highest was between husbands' marital satisfaction and their perception of their wives' humor use. One's own humor use and the perception of one's spouse's humor explained a remarkable $70 \%$ of the variance in marital satisfaction (Ziv and Gadish 1989: 766). Raniseski (1998: 1) and De Koning and Weiss (2002: 1) extended the investigation of humor and marital satisfaction. Investigating distancing and affiliative humor, Raniseski found that the more a husband perceived himself to use humor, the less marital well being he reported, but the more he perceived his wife using humor the greater well being he reported (1998: 65). For wives, the perception of humor use for herself and for her husband was unrelated to marital well being. De Koning and Weiss found that the perception that one's partner used positive humor was a stronger indicator of marital satisfaction than the respondent's own use of humor (2002: 11). In addition, less humor use and appreciation was found to relate to lower marital satisfaction. Rust and Goldstein found that among distressed couples there was less humor appreciation, and that the appreciation of a partner's humor correlated significantly with the general state of the marriage (1989: 221). These results strongly suggest that the perception of a partner's humor use is 
often a better predictor of marital well being than the respondent's own humor. That is, humor contributes more to the marital satisfaction of the audience than of the joker.

The relative contribution of humor in a relationship may depend more on how it is received than whether it is deployed. The way each partner interprets jokes determines whether humor will play a positive role or any role at all in the relationship. In this sense, it is critical to exploring humor's place in a relationship to consider how those behaviors are being received and interpreted. Different types of humor may result in very different outcomes. With the exception of Raniseski (1998: 26), researchers on humor in marriage generally do not differentiate types of humor. It is unclear which types of humor might lead to relational satisfaction. De Koning and Weiss (2002: 4) and Bippus (2000: 405) have developed functional inventories of humor in relationships, but these have yet to be explored in regard to relational outcomes. In addition, the value of offensive jokes has not been explored in the context of a relationship. To more fully consider humor's relative value to long-term relationships, it is necessary to consider the shared nature of humor and to delineate the specific effects of different types of humor. To do so, this study employs a coorientation approach to relationships. Ziv and Gadish (1989: 763), Raniseski (1998: 56), and De Koning and Weiss (2002: 13) explicitly call for the use of a coorientation approach to study humor because of its ability to account for both partners' perspectives and metaperspectives.

\section{Theoretical perspective}

The study of communication through the coorientation model has fallen in and out of favor since Newcomb (1953: 393, 1956: 575) introduced the theory. Drawn from Heider's balance theory and Festinger's concept of attitudinal congruence, Newcomb modeled two individuals in conversation through AtoBreX notation (where A and B are people and X is the object of communication). Maintaining an interpersonal relationship depends upon each person's orientation toward the other and their mutual orientation toward the object of communication (Newcomb 1953: 393, 1956: 575). McLeod and Chaffee extended the empirical formulation of Newcomb by refining the three central coorienation variables: congruence or perceived similarity, agreement or mutuality or actual similarity, and accuracy or understanding (1973: 485). Perceived similarity is the similarity between A's reported view of X and A's perception of B's view of X. In other words, it is "the similarity between the 
perception of the other person's feelings and your own feelings" (McLeod and Chaffee 1973: 473). Perceived similarity is more an intrapersonal than a true interpersonal variable because it is indexed by the degree of similarity between one person's cognitions and his/her perception of another's cognitions (McLeod and Chaffee 1973: 473). Actual similarity is measured by comparing two different people's perception of X. The final variable, understanding, refers to "the extent to which one person's estimate of the other person's cognitions match what the other person really does think" (McLeod and Chaffee 1973: 487). Perfect communication, in the literal sense, would occur when understanding is perfect - one communicator would know exactly what the other communicator believes about the topic of communication (McLeod and Chaffee 1973: 487). Coorientation theory takes into account the individual's perspective of him or herself and the individual's perspective of his/her partner and, therefore, offers unique advantages for the study of humor in relationships (De Koning and Weiss 2002: 13).

In relationships, humor is often most funny when it communicates something about the nature of the relationship between the two partners (Bippus 2000: 414; Ziv and Gadish 1989: 766). Humor is not inherently positive or negative; it is dependent on the joker, the joke, the audience, and the relationship between the joker and the audience. The effective use of humor by a spouse is strongly dependent upon the other spouse's perception of the joke's appropriateness. For example, when a partner effectively uses humor during relational conflict, it mitigates escalation and facilitates progress in the interaction (Bippus 2003: 422). Simply deploying humor during conflict is not enough; it must be done in a way that the partner perceives to be effective.

Research investigating perceived similarity in humor use has confirmed Newcomb's (1956: 582) original hypothesis that the perception of similarity is in itself rewarding. The perception of a shared sense of humor as well as a similarity in humor preference tends to predict marital satisfaction (De Koning and Weiss 2002: 13; Lauer et al. 1990: 194; Raniseski 1998: 67). When couples believe that humor is shared between them, they are more likely to be satisfied in marriage. Actual similarity within a dyad has also demonstrated a positive relationship to liking each other. For example, there is some limited evidence that similar appreciation of cartoons and jokes is related to greater levels of affinity. Murstein and Brust (1985: 640) found that actual similar humor preference in cartoons and jokes is correlated to mutual liking, and Rubin (1970: 270) found that the smaller the difference on the humor appreciation scores between young couples, the higher the love and liking scores. Priest and Thein (2003: 63), however, have since demonstrated only a weak and non- 
significant relationship between similarity in cartoon and joke appreciation and marital satisfaction. This suggests that actual similarity in humor preference might play a role in initial relationship development, but for long-term relationships actual similarity is not nearly as important as perceived similarity in humor use.

Little attention has been given to understanding, the final coorientation variable. Understanding is a complicated variable that reflects an ability to accurately know the other person's attitude or perception. Raniseski found that understanding of frequency of humor use positively predicted marital well being for husbands, but negatively predicted marital well being for wives (1998: 54). It appears that accurately knowing the husbands' use of humor for wives is not the same thing as liking it. When wives rate their husbands' use of humor as their husbands do, they may not be satisfied with this use of humor in their relationship. Husbands, however, appear to be satisfied with their marriages if they are able to see their wives as their wives see themselves. These findings deserve further research due to their complicated nature.

\section{Negative humor in relationships}

Negative uses of humor do not seem to relate to any other uses of humor in a relationship (Bippus 2000: 409; De Koning and Weiss 2002: 12; Graham et al. 1991: 177). It taps into a different construct than do instrumental, expressive, or positive types. Bergen demonstrates that negative humor is a means of expressing hostility, aggression, or sexual drives in a socially acceptable manner (1998: 340). It seems unlikely that sexist, racist, or otherwise negative humor use could positively impact a relationship. However, if these uses of humor were part of a larger humorous practice in the relationship, they might actually be a component of a positive whole. For example, those who have a highly humorous disposition are more likely to attempt jokes in multiple contexts and continue to try to be funny in the face of failure (Booth-Butterfield and BoothButterfield 1991: 215). Additionally, a person who has an earthy or boorish style of humor may deploy sexist or dirty jokes, but be regarded positively (Craik et al. 1996: 282). However, specific findings have yet to determine how negative types of humor relate to relational outcomes in long-term relationships.

Negative humor use depends largely on context. Innocuous jokes or anecdotes do no harm to the teller, unless they are not funny or annoying to the audience. Negative put-down jokes are particularly audience and context 
sensitive. Herzog and Anderson suggest that a sense of humor generally increases the appreciation of tasteless or cruel jokes (2000: 345). They argue that this response is not a question of how inappropriate the joke is, rather what emotion it evokes. Although most people respond to negative jokes negatively, those with an advanced sense of humor respond with a reframing interpretative response that renders the joke both wrong and funny in their eyes. In the context of a relationship, it is difficult to discern how offensive or put-down humor might be received. It is possible that the joker offends or irritates the spouse. It is equally possible that a spouse might have a high amount of contextual knowledge about the joker and his/her history, which allows for the reception of the joke with a reframing interpretation. The audience would then know that the speaker is clearly joking, not intending harm. As Herzog and Andersen note, however, these effects are highly moderated by gender (2000:347).

In their review of humor for unmatched men and women, Crawford and Gressley found no gender differences for six different types of humor (1991: 223). The gender differences they did find are particularly relevant to the present investigation. Men were more likely to enjoy hostile or discriminatory jokes. Another particular type of humor that differs between genders is sexist humor. Men consistently find anti-female sexist humor funnier than women do (Love and Deckers 1989: 653; Priest and Wilhelm 1974: 248; Zillman and Stocking 1976: 157), but women find anti-male humor funnier than men do (Priest and Wilhelm 1974: 248). The reception of sexist jokes is partly dependent on the joke teller (Ford et al. 2001: 687). When men tell sexist jokes it is perceived negatively, but when women tell anti-woman sexist jokes it is less critically received (Ford 2000: 1104). Men are also more likely to respond to cruel or tasteless jokes, while women had less tolerance for negative humor overall (Herzog and Anderson 2000: 347).

\section{Public and private negative humor}

Typologies of humor use in relationships (e.g. Bippus 2000: 403; De Koning and Weiss 2002: 8) suggest that negative humor is employed in relationships with only modest frequency. However, sexist and other negative types of humor are more commonly used in same-sex settings, which is necessarily a public use of humor (Hay 2000: 717). This distinction — between public and private humor use - has been relatively unexplored in literature on humor's role in relationships. Its importance lies in what negative humor might imply about the entire relationship. The use of negative humor in public is a potential 
embarrassment for the teller, but also for the teller's spouse. The same joke told in private is unlikely to be embarrassing, and might even be amusing depending on the partner's level of acceptance. If spouses observe their partners' public negative humor use, and they disapprove or dislike that behavior, it may have adverse effects on the relationship. It is unknown whether humor use in public differs in effect from humor use in private. But it is possible that the impact of humor use in public may be more negative than in private because of its reflection on both partners in a relationship.

In order to guide the present exploration of the benefits of negative humor in long-term relationships, we offer the following three research questions:

RQ1 - What impact does negative humor use have on relational satisfaction and the overall importance of humor in the relationship, controlling for positive humor creation?

$R Q 2$ - Do perceived similarity, understanding, and actual similarity of negative humor use impact relational satisfaction and the importance of humor in the relationship?

RQ3 - Does the use of negative public or private humor show a stronger relationship with relational satisfaction and the importance of humor in the relationship?

\section{Methods}

\subsection{Sample}

One hundred and twenty-three male-female couples completed the survey instrument. Participants were asked to identify the highest level of education they had completed on an ordinal scale, and the median level of education was "some college." The sample was 51\% Caucasian, 21\% Asian American, 17\% Latino, 4\% African American, and 7\% other or mixed race. The average age was 36 (range 18 to 77 ). The average length of the relationship was 12.5 years. Seventy-five percent of the couples were married and $25 \%$ were living together but unmarried.

\subsection{Procedures}

The respondents were recruited by asking students in an introductory communication course at a mid-sized private university to request that their parents or 
other married adults complete the instrument. No course credit was offered in exchange for a completed survey and participation was completely voluntary. No identifying information was collected, and all data collection procedures were approved by the Institutional Review Board.

\subsection{Measures}

The instrument assessed the participant's use of humor and the participant's perception of his/her partner's use of humor. The instrument measured both public and private use, and attempted to capture positive humor types (e.g. silly behavior, PG-rated jokes) and negative humor types of humor (e.g. racist jokes, sexist jokes). This instrument measured offensive comments intended as jokes and inappropriate joke telling in order to address existing literature on offensive joke appreciation. These items were chosen in accordance with Honeycutt and Brown's suggestion that joke telling and making comments intended to be funny is most associated with production of humor (1998: 349). The five items assessing marital satisfaction and four items assessing the importance of humor in the relationship were scaled on a 5-point semantic differential scale format ("Totally satisfied" to "Totally unsatisfied"). (Relational satisfaction items: "How satisfied are you with your relationship?" "How satisfied do you feel your partner is with your relationship?" "Overall, how would you describe your marriage or relationship?" "Overall, how satisfied are you with your spouse or partner?" "How satisfied are you with the stability you feel in your marriage?").

The variables used to analyze negative humor use in relationships were created in four steps. In the first step, two confirmatory factor analyses (CFA) were conducted to determine whether the items created to measure marital satisfaction (five items) and importance of humor in the relationship (four items) were observed in the measurement model. Reliability tests yielded good results ( $\alpha$ for importance $=.88, \alpha$ for relational satisfaction $=.87$ ). Using the LISREL 8.54 program, a two-factor oblique model reported a $\chi 2$ value of 68.9 , which was significant $(d f=18, p<.01)$. The obtained value was significantly better than the null model $(\chi 2=1983.9, d f=55)$. Additionally, the $\chi 2 / d f$ ruleof-thumb was below the recommended value of $5(\chi 2 / d f=3.8)$, and the CFI was 0.97, indicating an acceptable fit (Byrne 1998: 147). The weightings generated for each of the items were used to calculate a sum score of overall relational satisfaction of self, and overall importance of humor in the relationship for self. (Importance of humor items: "Overall, how do you judge the effect of 
the use of humor in your relationship?" "Overall, how do you feel your partner would judge the effect of the use of humor in your relationship?" "How important is the use of humor to your satisfaction in the relationship?" "How important do you feel the use of humor is to your relationship overall?").

The second step determined which of the items were considered to be negative types of humor. Participants were asked to rate how they believed their partner feels about their use of each type of humor, and how they felt about their partner using each type of humor on a five point semantic differential scale ("Very Bad" to "Very Good"). Both the amount of humor used and feelings about that type of humor were measured. Feelings about humor use defined whether it was positive or negative while amount of use was the primary variable in subsequent analyses. Types of humor which scores less than 3.0 for both participants and for participants' report of their partners' use were considered to be a negative type of humor. Sexist, racist, religious put-down, and physical disability jokes were considered negative types of humor in both public and private. Dirty sexual jokes were only considered negative types of humor when used in public. Table 1 lists the types of humor, and the mean use and feeling scores. An alpha score was calculated for the private and public negative humor items and was acceptable (private $\alpha=.89$, public $\alpha=.87$ ).

For the third step, perceived similarity, actual similarity, and understanding variables were created for each respondent using the Spearman's Rho

Table 1. Use and partner's feelings means and standard deviations for public and private Humor items $(N=246)$

\begin{tabular}{|c|c|c|c|c|}
\hline \multirow[b]{2}{*}{ Items } & \multicolumn{2}{|c|}{ Self use } & \multicolumn{2}{|c|}{ Partner's feelings } \\
\hline & Mean & $\mathrm{SD}$ & Mean & $\mathrm{SD}$ \\
\hline \multicolumn{5}{|l|}{ Public } \\
\hline Racist jokes & 1.72 & .83 & 2.49 & 1.13 \\
\hline Sexist jokes & 1.89 & .90 & 2.60 & 1.11 \\
\hline Religion demeaning jokes & 1.64 & .82 & 2.42 & 1.13 \\
\hline Dirty jokes or stories & 2.06 & .97 & 2.91 & 1.07 \\
\hline Disability insensitive jokes & 1.51 & .79 & 2.25 & 1.13 \\
\hline \multicolumn{5}{|l|}{ Private } \\
\hline Racist jokes & 2.08 & .99 & 2.75 & .85 \\
\hline Sexist jokes & 2.08 & 1.03 & 2.90 & 1.09 \\
\hline Religion demeaning jokes & 1.78 & .94 & 2.67 & 1.16 \\
\hline Disability insensitive jokes & 1.65 & .93 & 2.42 & 1.16 \\
\hline
\end{tabular}

Note: Humor use items are measured on a five point Likert-type scale, where $5=$ "All the time" and $1=$ "Never." Feelings about humor use are measured on a five point Likert-type scale, where 5 = "Very Positively" and 1 = "Very Negatively." 
Table 2. Means and standard deviations for variables $(N=246)$

\begin{tabular}{lrrrrr}
\hline & \multicolumn{2}{c}{ Private } & & \multicolumn{2}{c}{ Public } \\
\cline { 2 - 3 } \cline { 6 - 7 } Variables & Mean & SD & & Mean & SD \\
\hline Actual similarity & .73 & .20 & & .62 & .29 \\
Perceived similarity & .83 & .18 & & .73 & .30 \\
Understanding & .77 & .20 & & .66 & .29 \\
Negative humor use & 1.90 & .84 & & 1.77 & .70 \\
Importance of humor & 7.24 & 2.55 & & - & - \\
Relational satisfaction & 20.15 & 2.90 & & - & - \\
\hline
\end{tabular}

Note: Importance and relational satisfaction are the same for both public and private humor use because they are global measures, and not specific to public and private humor use.

correlation method described by Purnine and Carey (1999: 1018). In comparison to difference scores, this method decreases the overall error variance and provides a more accurate measure of the statistical and theoretical relationship between partners' responses (Purnine and Carey 1999: 1018). For perceived similarity, the participant's reported use and participant's assessment of his or her partner's use were correlated. For actual similarity, the participant's reported use and participant's partner's reported use were correlated. For understanding, participant's assessment of partner's use and partner's reported use were correlated. Except for actual similarity the correlation coefficients calculated were different between partners. The coorientation variables were calculated for both public and private negative humor. For a summary of all variables see Table 2 .

\section{Results}

To examine the difference between partners' negative humor use, two 2-tailed $\mathrm{t}$ tests were conducted. Men reported using negative humor more than their partners in public, $t(246)=2.43, p<.05$, and in private $t(246)=2.29, p<.05$. Two-tailed t tests were conducted to test the difference between the amount of public and private negative humor men and women reported their partners using. Consistent with participant's rating of their own humor use, women reported their partners using more negative public $(t(246)=2.20, p<.05)$ and private humor $(t(246)=2.71, p<.01)$ than men reported their partners using. Women did not report using humor significantly more than their partners perceived them to in public ( $M=1.65$ and $M=1.58$, respectively), nor in private $(M=1.78$ and $M=1.80)$. In addition, men did not report using humor signifi- 
cantly more than their partners perceived them to in public $(M=1.87$ and $M=1.80)$, nor in private $(M=2.02$ and $M=2.11)$. Men and women both agree, by self-assessment and by assessment of their partners, that men use more negative humor in public and private than women.

\subsection{Dyadic analysis}

When data is collected from both partners in a relationship, partners' responses are often highly related to one another. In the present study, each partner's relational satisfaction and humor importance are dependent upon one another, as reflected in their correlations, which ranged from .20 to .57. Therefore, the dyadic data collected for this study cannot be assumed to be independent (Kenny et al. 2006: 4). The relationship between partners' humor use and partners' relational satisfaction is at the center of the present investigation. Therefore, rather than analyzing these data at the individual level, we used the dyad as the unit of analysis. Kenny and colleagues suggest that when dyadic data are collected and the dyads are distinguishable researchers should use structural equations modeling (2006: 101). Specifically, the Actor-Partner Independence Model (APIM) allows researchers to estimate the impact of husbands' negative humor use on their own relational satisfaction (actor effect), and on their wives' relational satisfaction (partner effect), controlling for positive humor use (see Figure 1). The following analyses of negative humor use were estimated using APIM and structural equations modeling.

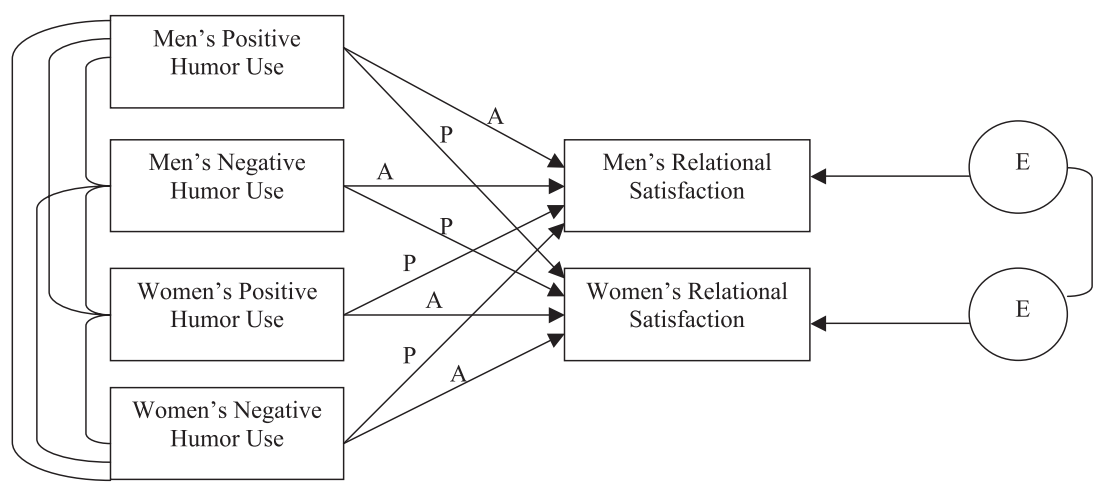

Note: All actor effects labeled "A" and all partner effects labeled "P"

Figure 1. APIM for effects of private negative and private positive humor use on relational satisfaction 


\subsection{Private humor use}

The first APIM analyses determined whether participants' negative humor use in private is related to their relational satisfaction and that of their partner, controlling for positive humor use. Negative humor used in private failed to demonstrate an actor or partner effect. Men's positive humor use, however, predicted their partner's relational satisfaction $(\beta=.65, p<.05)$, and approached significance for their own relational satisfaction $(\beta=.58, p<.10)$. The second APIM analysis determined whether participants' negative humor use in private predicted the importance of humor in the relationship, controlling for positive humor use. The relationship between men's own negative humor use and humor's importance for men was negative and approached significance $(\beta=-.69, p<.10)$. In addition, there was a consistent actor effect for positive humor use: women's positive humor use increased humor's importance for women $(\beta=.77, p<.01)$, and men's positive humor use increased humor's importance for men $(\beta=1.05, p<.001)$. For complete results see Table 3 .

Table 3. SEM estimates of effects of private negative and positive private humor use on relational satisfaction and the importance of humor for dyad (unstandardized beta weights) $(N=123)$

\begin{tabular}{|c|c|c|c|c|}
\hline \multirow[b]{2}{*}{ Variables } & \multicolumn{2}{|c|}{$\begin{array}{l}\text { Men's } \\
\text { relational satisfaction }\end{array}$} & \multicolumn{2}{|c|}{$\begin{array}{l}\text { Women's } \\
\text { relational satisfaction }\end{array}$} \\
\hline & $\beta$ & $t$ & $\beta$ & $t$ \\
\hline \multicolumn{5}{|l|}{ Men } \\
\hline Negative private use & -.58 & -1.29 & -.68 & -1.57 \\
\hline Positive private use & .58 & $1.72+$ & .65 & $1.99 *$ \\
\hline \multicolumn{5}{|l|}{ Women } \\
\hline Negative private use & .87 & 1.47 & -.33 & -.57 \\
\hline \multirow[t]{2}{*}{ Positive private use } & -.46 & -1.16 & .57 & 1.49 \\
\hline & \multicolumn{2}{|c|}{$\begin{array}{l}\text { Men's } \\
\text { importance of humor }\end{array}$} & \multicolumn{2}{|c|}{$\begin{array}{l}\text { Women's } \\
\text { importance of humor }\end{array}$} \\
\hline \multicolumn{5}{|l|}{ Men } \\
\hline Negative private use & -.69 & $-1.90+$ & -.14 & -.41 \\
\hline Positive private use & 1.05 & $3.85 * * *$ & .38 & 1.52 \\
\hline \multicolumn{5}{|l|}{ Women } \\
\hline Negative private use & .10 & .21 & -.35 & -.79 \\
\hline Positive private use & .27 & .82 & .77 & $2.58 *$ \\
\hline
\end{tabular}

Note: ${ }^{+} p<.10, * p<.05, * * p<.01 * * * p<.001$ 
The next APIM analyses explored the relationship between relational satisfaction and coorientation variables, controlling for positive private humor use. Both men and women's perceived similarity and understanding variables were considered in the same model. Although partners' coorientation variables are nonindependent, each partner has a different score. Actual similarity in private negative humor use was considered at the dyad level because each couple shared the same score. Results indicate that women's perceived similarity in private negative humor use was positively related to their own relational satisfaction ( $\beta=.73, p<.05)$, but men's perceived similarity was not related to their own, nor to their partner's relational satisfaction. Men's understanding of their partner's private use of negative humor was negatively related to their own relational satisfaction $(\beta=-.78, p<.05)$. That is, as men's understanding increases, men's relational satisfaction decreases. No relationship between understanding and relational satisfaction was found for women. Furthermore, analyses revealed no relationship between actual similarity in negative private humor use and relational satisfaction.

Repeating these analyses with the importance of humor in the relationship as the dependent variable yielded similar results as prior analyses of humor's impact on relational satisfaction. No relationship between negative private humor use and the importance of humor was revealed. Results did demonstrate a consistent actor effect for positive humor use. Women's positive humor use increased humor's importance for women ( $\beta=.53, p<.01)$, and men's positive humor use increased humor's importance for men $(\beta=.97, p<.001)$. The coorientation variables failed to demonstrate a significant relationship with the importance of humor, save one: the relationship between men's perceived similarity of negative humor use and the importance of humor for men $(\beta=.65$, $p<.01)$. That is, the more men perceive their wives to use negative humor in a way similar to themselves, the more positively they evaluate humor's importance to their relationship. For complete results of private negative humor coorientation analyses, refer to Table 4.

\subsection{Public humor use}

The next analyses explored the effects of public negative humor use. Men's positive and negative humor use in public bore no relationship with their own or their partners' relational satisfaction. However, women's positive humor use in public positively predicted their own relational satisfaction $(\beta=1.24$, $p<.001)$. The relationship between women's negative humor use in public and 
Table 4. SEM estimates of effects of coorientation variables and positive private humor use on relational satisfaction and the importance of humor for dyad (unstandardized beta weights) $(N=123)$

\begin{tabular}{|c|c|c|c|c|}
\hline \multirow[b]{2}{*}{ Variables } & \multicolumn{2}{|c|}{$\begin{array}{l}\text { Men's } \\
\text { relational satisfaction }\end{array}$} & \multicolumn{2}{|c|}{$\begin{array}{l}\text { Women's } \\
\text { relational satisfaction }\end{array}$} \\
\hline & $\beta$ & $t$ & $\beta$ & $t$ \\
\hline \multicolumn{5}{|l|}{ Men } \\
\hline Perceived similarity & .40 & 1.25 & .32 & 1.03 \\
\hline Understanding & -.78 & $-2.24 *$ & -.44 & -1.32 \\
\hline Positive private humor & .54 & $1.91+$ & .57 & $2.13^{*}$ \\
\hline \multicolumn{5}{|l|}{ Women } \\
\hline Perceived similarity & .10 & .29 & .73 & $2.17^{*}$ \\
\hline Understanding & .30 & .85 & .11 & .32 \\
\hline Positive private humor & -.37 & -.85 & .21 & .70 \\
\hline \multirow[t]{2}{*}{ Actual similarity for couple } & .04 & .12 & .19 & .67 \\
\hline & \multicolumn{2}{|c|}{$\begin{array}{c}\text { Men's } \\
\text { importance of humor }\end{array}$} & \multicolumn{2}{|c|}{$\begin{array}{l}\text { Women's } \\
\text { importance of humor }\end{array}$} \\
\hline \multicolumn{5}{|l|}{ Men } \\
\hline Perceived similarity & .65 & $2.47 *$ & .06 & .25 \\
\hline Understanding & -.11 & .38 & -.15 & .55 \\
\hline Positive private humor & .97 & $4.21 * * *$ & .35 & $1.65+$ \\
\hline \multicolumn{5}{|l|}{ Women } \\
\hline Perceived similarity & .06 & .21 & .13 & .50 \\
\hline Understanding & -.14 & -.49 & -.06 & -.23 \\
\hline Positive private humor & .17 & .66 & .53 & $2.17 *$ \\
\hline Actual similarity for couple & .14 & .57 & .18 & .78 \\
\hline
\end{tabular}

Note: ${ }^{+} p<.10, * p<.05, * * p<.01 * * * p<.001$

their own relational satisfaction was negative and approaching significance $(\beta=1.07, p<.10)$. Repeating this analysis with the importance of humor as the dependent variable yielded different results. Men's public negative humor use negatively predicted humor's importance for men $(\beta=-.93, p<.05)$. Additionally, a consistent actor effect for public positive humor use was found. Women's positive public humor use increased humor's importance for women $(\beta=.83, p<.01)$, and men's positive public humor use increased humor's importance for men $(\beta=.89, p<.001)$. For complete results see Table 5 .

The final pair of APIM analyses explored the relationship between relational satisfaction and the importance of humor and coorientation variables regarding public humor use. When men perceived similarity in public negative humor use, both men's relational satisfaction $(\beta=.74, p<.05)$ and women's rela- 
Table 5. SEM estimates of effects of negative and positive public humor use on relational satisfaction and the importance of humor for dyad (unstandardized beta weights) $(N=123)$

\begin{tabular}{|c|c|c|c|c|}
\hline \multirow[b]{2}{*}{ Variables } & \multicolumn{2}{|c|}{$\begin{array}{l}\text { Men's } \\
\text { relational satisfaction }\end{array}$} & \multicolumn{2}{|c|}{$\begin{array}{l}\text { Women's } \\
\text { relational satisfaction }\end{array}$} \\
\hline & $\beta$ & $t$ & $\beta$ & $t$ \\
\hline \multicolumn{5}{|l|}{ Men } \\
\hline Negative public use & -.37 & -.73 & -.38 & -.79 \\
\hline Positive public use & .11 & .31 & .16 & .48 \\
\hline \multicolumn{5}{|l|}{ Women } \\
\hline Negative public use & .18 & .28 & -1.07 & $-1.73+$ \\
\hline \multirow[t]{2}{*}{ Positive public use } & .17 & .38 & 1.24 & $3.02 * * *$ \\
\hline & \multicolumn{2}{|c|}{$\begin{array}{c}\text { Men's } \\
\text { importance of humor }\end{array}$} & \multicolumn{2}{|c|}{$\begin{array}{l}\text { Women's } \\
\text { importance of humor }\end{array}$} \\
\hline \multicolumn{5}{|l|}{ Men } \\
\hline Negative public use & -.93 & $-2.20 *$ & -.13 & -.36 \\
\hline Positive public use & .89 & $3.12 * * *$ & .19 & .74 \\
\hline \multicolumn{5}{|l|}{ Women } \\
\hline Negative public use & .76 & 1.39 & -.15 & -.30 \\
\hline Positive public use & .09 & .24 & .83 & $2.56^{*}$ \\
\hline
\end{tabular}

Note: ${ }^{+} p<.10, * p<.05, * * p<.01 * * * p<.001$

tional satisfaction $(\beta=.70, p<.05)$ were positively affected. Women's understanding demonstrated an inverse relationship with men's relational satisfaction $(\beta=-.65, p<.05)$. That is, as women's understanding of their partners' public negative humor use increased, men's relational satisfaction decreased. No relationship between understanding and relational satisfaction was found for men. In addition, actual similarity in public negative humor use was unrelated to relational satisfaction.

Repeating these analyses with the importance of humor in the relationship as the dependent variable also demonstrated a consistent actor effect for positive humor use. Women's public positive humor use increased humor's importance for women $(\beta=.61, p<.05)$, and men's positive humor use increased humor's importance for men $(\beta=.66, p<.001)$. Two coorientation variables revealed significant relationships. Men's perceived similarity of negative public humor use increased the importance of humor for men $(\beta=.96, p<.001)$ and women's understanding of their partner's public negative humor use was negatively related to the importance of humor for women $(\beta=.50, p<.05)$. That is, the more women accurately estimated their partner's use of public 
Table 6. SEM estimates of effects of coorientation variables and public positive humor use on relational satisfaction and the importance of humor for dyad (unstandardized beta weights) $(N=123)$

\begin{tabular}{|c|c|c|c|c|}
\hline \multirow[b]{2}{*}{ Variables } & \multicolumn{2}{|c|}{$\begin{array}{l}\text { Men's } \\
\text { relational satisfaction }\end{array}$} & \multicolumn{2}{|c|}{$\begin{array}{l}\text { Women's } \\
\text { relational satisfaction }\end{array}$} \\
\hline & $\beta$ & $t$ & $\beta$ & $t$ \\
\hline \multicolumn{5}{|l|}{ Men } \\
\hline Perceived similarity & .74 & $2.07 *$ & .70 & $2.02 *$ \\
\hline Understanding & -.52 & 1.30 & -.33 & -.85 \\
\hline Positive public humor & .07 & .27 & .17 & .67 \\
\hline \multicolumn{5}{|l|}{ Women } \\
\hline Perceived similarity & -.34 & -.95 & .13 & .39 \\
\hline Understanding & -.65 & $-1.96^{*}$ & -.26 & -.82 \\
\hline Positive public humor & -.17 & -.47 & .60 & $1.68+$ \\
\hline \multirow[t]{2}{*}{ Actual similarity for couple } & .48 & 1.22 & .22 & .58 \\
\hline & \multicolumn{2}{|c|}{$\begin{array}{l}\text { Men's } \\
\text { importance of humor }\end{array}$} & \multicolumn{2}{|c|}{$\begin{array}{l}\text { Women's } \\
\text { importance of humor }\end{array}$} \\
\hline \multicolumn{5}{|l|}{ Men } \\
\hline Perceived similarity & .96 & $3.16^{* * *}$ & .27 & 1.00 \\
\hline Understanding & -.39 & -1.16 & -.21 & -.69 \\
\hline Positive public humor & .66 & $2.90 * * *$ & .12 & .60 \\
\hline \multicolumn{5}{|l|}{ Women } \\
\hline Perceived similarity & -.21 & -.69 & .31 & 1.14 \\
\hline Understanding & -.38 & -1.35 & -.50 & $-1.97 *$ \\
\hline Positive public humor & .15 & .47 & .61 & $2.18 *$ \\
\hline Actual similarity for couple & .05 & .14 & .08 & .27 \\
\hline
\end{tabular}

Note: ${ }^{+} p<.10, * p<.05, * * p<.01 * * * p<.001$

negative humor, the less importance humor had for them. For complete results of public negative humor use coorientation analyses refer to Table 6.

\section{Discussion}

The present investigation set out to understand what role negative humor, used in private and public, has on a couple's relational satisfaction and on the overall importance of humor in the relationship. Results suggest that use of negative humor, whether in private or in public, has little to no influence on relational outcomes. The benefits and drawbacks of negative humor use emerge only when the individual is investigated within the context of his/her relation- 
ship. First, the effects of negative and positive humor use are discussed at the individual level, and then the effects of the perceptions and metaperceptions of negative humor use are discussed.

Results indicate that men use more negative humor than women, both in public and in private. This replicates prior research on gender difference in humor by Herzog and Andersen (2000: 347) and Hay (2000: 737). Does the greater use of negative humor by men affect the couple's relational satisfaction? When considering the raw or total amount of negative humor used by each partner, the answer is no. When controlling for positive humor use, negative humor use in public or in private had no affect on relational satisfaction. Positive humor use, however, does increase relational satisfaction. Women reported more relational satisfaction when their husbands use positive private humor. These findings confirm similar results found by Ziv and Gadish (1989: 764), which suggests that women are benefited by their husbands' humor use. Women also reported being happier with their relationship when they used more positive humor in public. In sum, when women use positive humor in public and when their husband uses positive humor in private, women are happier in their relationships.

The analyses exploring the relationship between negative humor production and the overall importance of humor revealed the one significant detriment of negative humor use. For men, greater use of negative humor in public negatively impacts the importance men assign to humor in their relationship. It appears that men recognize that public negative humor use - in excess of their positive humor creation - diminishes the overall value of humor for their relationship. Similar to the above analyses of relational satisfaction, private and public positive humor use have a strong and consistently positive relationship with humor's importance to the relationship for both men and women. This confirms Lauer and colleagues finding that couples who believe humor is important will seek opportunities to crack jokes and laugh (1990: 194). In sum, when considered as a raw amount, negative humor use has no impact on relational satisfaction, and a negative impact on the importance humor for men.

\subsection{Coorientation}

The most interesting and revealing analyses explored the use of negative humor in the context of the dyad. Overall, the coorientation variables were better predictors of relational outcomes than were measurements of raw amounts of negative humor use. Perceived similarity and understanding demonstrated 
interesting and sometimes complex relationships with relational outcomes, while actual similarity in negative humor use failed to demonstrate these relationships. Actual similarity in humor use has failed to predict relational satisfaction in prior research as well (e.g. Priest and Thein 2003: 73; Raniseski 1998: 74), which suggests that in long-term relationships actual similarity is not a good indicator of relational outcomes. A further discussion of perceived similarity and understanding should clarify the impact of negative humor use in relationships.

For men, the perception of similar negative humor use both in private and in public positively predicted the importance of humor in the relationship. Greater similarity implies the perception of a shared sense of humor. When men see themselves as sharing a sense of humor with their partners, humor takes on greater importance in the relationship. These findings reinforce past research that suggests men's perceptions of women's use of humor consistently relates to the value of humor in a relationship (Raniseski 1998: 65; Ziv and Gadish 1989: 764). If partners perceive equivalent amounts of negative humor use it also impacts relational satisfaction. Men who believe they are using the same amount of negative humor as their wives in public are happier in their relationship. Sharing a sense of humor about potentially offensive topics may make men happier because they feel their partner really 'gets' their sense of humor and appreciates it, even when they are acting in potentially inappropriate ways. Interestingly, when a man thinks he shares a sense of negative humor with his partner, his partner also reports greater relational satisfaction. This is particularly interesting considering that perceived similarity is an intrapersonal variable: it compares one's own behaviors with one's perception of a partner's behavior. A woman might be happier with the relationship when her husband perceives similarity because she experiences greater trust or appreciation when he sees her as an insider to his public offensive joking. Since this study is the first to explore the effects of negative public humor using the Actor-Partner Independence Model, the partner effects of perceived similarity should be replicated in future research.

Perceived similarity is somewhat less predictive of relational outcomes for women. No matter how much positive humor a woman creates, she is more satisfied with her relationship when she believes her partner uses the same amount of negative humor as she does in private. This confirms Raniseski's (1998: 65) finding that perceived similarity for women relates to relational well being. Since women use less negative humor in general, this might mean that when women perceive their partners as using a small amount of negative humor, they are more satisfied with their relationship. 
Understanding demonstrated a complex relationship with relational satisfaction. Understanding refers to the extent to which one person's estimate of the other person's behavior matches what the other person actually does. For men, understanding private humor use negatively predicts relational satisfaction. That is, when men inaccurately assess how much negative humor their partner is using in private, they report more relational satisfaction. Men who accurately assess their partners' negative humor use in private are less happy with their relationship. In attempts to explain similar findings, Raniseski suggested that accurately knowing a negative behavior does not imply liking it (1998: 74). Another, more positive interpretation is that being inaccurate allows men to continue to perceive humor use in whatever way is positive for them. This inverse relationship between understanding and relational satisfaction was also found for women, but rather than affecting their own relational satisfaction, it affected their partner's relational satisfaction. Women's understanding of their partners' public humor use negatively relates to men's relational satisfaction. That is, when women really know how much negative humor their partner used, men are not very happy about it. This implies that somehow women communicate their dissatisfaction with knowing their partners' public negative humor use, which leads to men being less satisfied with their relationship. It is also possible that inaccurate knowledge of men's negative public humor use by women allows men to continue using negative public humor without sanction from their partners, which leads to greater relational satisfaction. These results suggest that ignorance of actual negative humor use can be a benefit, particularly for men. Men are happier when ignorant of their partners' negative private humor use. In addition, men are happier when their partners are ignorant of their own negative public humor use.

\subsection{Public/private}

One of the goals of this project was to explore the relative benefits of private versus public use of negative humor. Overall, men and women exhibited a preference for similarity in use for both types of humor. For example, perceived similarity of both types of negative humor use increased the importance of humor for men. Women's relational satisfaction was also boosted when they perceived similarity in private humor use, and when their partners perceived similarity in public humor use. Upon closer inspection, public negative humor use seemed to be associated with greater negative outcomes. There are two findings that support this position. When considering raw amounts of negative 
humor use, men were less likely to see humor as important to the relationship when they used greater amounts of negative public humor. Conversely, private humor use did not directly affect relational outcomes when considered as a raw amount. Second, accurately estimating partners' public negative humor use was associated with more negative outcomes than private humor use. When women accurately assessed their partners' public humor use, they evaluated humor as less important and their partners were less satisfied with the relationship. These findings suggest that the use of negative humor in public reduces the value of humor for the teller, which is more likely to be a man, and accurately knowing this behavior diminishes the value of humor for joker's partner. In private, negative humor has little direct effects. In fact, it even might be amusing if the partners perceive similarity in their behavior. The distinction between public and private humor use has been relatively unexplored, and deserves further attention. Future research may consider public humor use in terms of embarrassment, shame, or irritation in order to better capture how public humor use might lead to these negative outcomes.

\section{Conclusions}

It appears that negative humor plays an auxiliary role in a relationship, one that is most valuable when both partners see themselves as equal in their negative joking. While positive humor use in public and private demonstrate consistent, positive benefits for joker and sometimes the audience, negative humor use is highly dependent on the couple. Perceived similarity in negative humor use positively predicts relational satisfaction for both partners, and positively predicts the importance of humor for men. Although men acknowledge that their own negative humor use negatively impacts the importance of humor, especially in public, they seem to positively regard their wives making a similar amount of offensive jokes as themselves, no matter how much positive humor the couple uses. The value of perceived similarity and the lack of value of actual similarity reinforces past research (e.g., Priest and Thein 2003: 73; Raniseski 1998: 74), and affirms the importance of considering the couple as two parts of a whole, not just separate individuals. Finally, the relationship between humor use and understanding needs to be explored more thoroughly, but the findings here indicate that sometimes ignorance of actual humor use is a positive influence in the relationship. It is important to note that the negative relationship between understanding and relational outcomes was also found in 
Raniseski's (1998: 74) work, which suggests that although these relationships are complex, they not without precedent in prior coorientation research.

\subsection{Limitations and directions for future research}

Although this research has helped to address a lack of study of negative humor in relationships, much work needs to be done. First, only negative and discriminatory jokes were considered, not put down jokes directed at a relational partner. Teasing, sarcasm, put-downs, and demeaning humor are very unlikely to exhibit any of the positive affects of perceived similarity reported here, but do deserve future attention. The coorientation perspective continues to be fruitful, particularly perceived similarity, and ought to be utilized in future research on humor. One coorientation variable, understanding, continues to provide interesting and complex results, and the results reported here should be replicated. Future research might also try to ascertain whether an optimal level of negative humor might exist, or whether this level might be identified in relation to each partner's use. It could be that the optimal level is very little or none, or that the amount is dependent upon the couple's shared sense of humor. The present investigation explored negative humor use controlling for the positive humor, which diminishes the possibility that these results are just a consequence of being a humorous person and demonstrates that negative humor has a unique impact on relationships. In summary, humor in relationships is valuable, but how valuable it is depends on the type of humor used and the perceptions and metaperceptions of the couple.

University of Kansas

University of Southern California

\section{Note}

Correspondence addresses: hallj@ku.edu; sereno@usc.edu

\section{References}

Alberts, Jess K., Christina G. Yoshimura, Michael Rabby \& Rose Loschiavo. 2005. Mapping the topography of couples' daily conversation. Journal of Social and Personal Relationships 22. 299-322. 
Bergen, Doris. 1998. Development of the sense of humor. In Willibald Ruch (ed.), The sense of humor: Explorations of a personality characteristic, 329-360. Berlin \& New York: Mouton de Gruyter.

Bippus, Amy M. 2000. Making sense of humor in young romantic relationships: Understanding partners' perceptions. Humor: International Journal of Humor Research 13(4). 395-417.

Bippus, Amy M. 2003. Humor motives, qualities, and reactions in recalled conflict episodes. Western Journal of Communication 67. 413-430.

Booth-Butterfield, Steven \& Melanie Booth-Butterfield. 1991. Individual differences in the communication of humorous messages. Southern Communication Journal 56. 205-218.

Craik, Kenneth. H., Martin D. Lampert \& Arvalea J. Nelson. 1996. Sense of humor and everyday styles of humorous conduct. Humor: International Journal of Humor Research 9. 273-302.

Crawford, Mary \& Diane Gressley. 1991. Creativity, caring, and context. Psychology of Women Quarterly 15. 217-231.

De Koning, Erica \& R. L. Weiss. 2002. The relational humor inventory: Functions of humor in close relationships. American Journal of Family Therapy 30(1). 1-18.

Ford, Thomas E. 2000. Effects of sexist humor on tolerance of sexist events. Personality and Social Psychology Bulletin 26. 1094-1107.

Ford, Thomas E., Erin R. Wentzel \& Joli Lorion. 2001. Effects of exposure to sexist humor on perceptions of normative tolerance of sexism. European Journal of Social Psychology 31. 677 691.

Graham, Elizabeth E., Michael J. Papa \& Gordon P. Brooks. 1991. Functions of humor in conversation: Conceptualization and measurement. Western Journal of Communication 56(2). 161183.

Hay, Jennifer. 2000. Functions of humor in the conversations of men and women. Journal of Pragmatics 32. 709-43.

Herzog, Thomas R. \& Maegan R. Andersen. 2000. Joke cruelty, emotional responsiveness, and joke appreciation. Humor: International Journal of Humor Research 13. 333-351.

Honeycutt, James M. \& Renee Brown. 1998. Did you hear the one about?: Typological and spousal differences in planning of jokes and sense of humor in marriage. Communication Quarterly 46. 342-352.

Kenny, David A., Deborah A. Kashy \& William L. Cook. 2006. Dyadic data analysis. New York: The Guilford Press.

Lauer, Robert H., Jeanette C. Lauer \& Sarah T. Kerr. 1990. The long-term marriage: Perception of stability and satisfaction. International Journal on Aging and Human Development 31(3). 189195.

McLeod, Jack M. \& Steven H. Chaffee. 1973. Interpersonal approaches to communication research. American Behavioral Scientist 16. 469-499.

Murstein, Bernard I. \& Robert G. Burst. 1985. Humor and interpersonal attraction. Journal of Personality Assessment 49. 637-640.

Newcomb, Thomas M. 1953. An approach to the study of communicative acts. Psychological Review 60. 393-404.

Newcomb, Thomas M. 1956. The prediction of interpersonal attraction. American Psychologist 11. 575-586.

Priest, Robert F. \& Melinda T. Thein. 2003. Humor appreciation in marriage: Spousal similarity, assertive mating, and disaffection. Humor: International Journal of Humor Research 16(1). 63-78.

Priest, Robert F. \& Paul Wilhelm. 1974. Sex, marital status, and self-actualization as factors in the appreciation of sexist jokes. Journal of Social Psychology 92. 245-249.

Purine, Daniel M. \& Michael P. Carey. 1999. Dyadic coorientation: Reexamination of a method for studying interpersonal communication. Archives of Sexual Behavior 28. 45-62. 
Raniseski, Jean M. A. 1998. Exploring the relationships between humor and marital well-being. Dissertation Abstracts International 59. 3124.

Rubin, Zick. 1970. Measurement of romantic love. Journal of Personality and Social Psychology 16. 265-273.

Rust, John \& Jeffrey Goldstein. 1989. Humor in marital adjustment. Humor: International Journal of Humor Research 2. 217-224.

Seckman, Mark A. \& Carl J. 1989. Jocularity, sarcasm, and relationships: An empirical study. Journal of Contemporary Ethnography 18(3). 327-344.

Ziv, Avner. 1988. Humor's role in married life. Humor: International Journal of Humor Research 1. 223-229.

Ziv, Avner \& Orit Gadish. 1989. Humor and marital satisfaction. Journal of Social Psychology 129. 759-768.

Zillmann, Dolf \& Holly S. Stocking. 1976. Putdown humor. Journal of Communication 26. 154 163. 
Copyright of Humor: International Journal of Humor Research is the property of De Gruyter and its content may not be copied or emailed to multiple sites or posted to a listserv without the copyright holder's express written permission. However, users may print, download, or email articles for individual use. 